Review

\title{
Isotype Diversification of IgG Antibodies to HIV Gag Proteins as a Therapeutic Vaccination Strategy for HIV Infection
}

\author{
Martyn A. French ${ }^{1,2, *}$, Laila N. Abudulai ${ }^{1}$ and Sonia Fernandez ${ }^{1}$ \\ 1 School of Pathology and Laboratory Medicine, University of Western Australia, Perth 6009, Australia \\ 2 Department of Clinical Immunology, Royal Perth Hospital and PathWest Laboratory Medicine, \\ Perth 6000, Australia
}

* Author to whom correspondence should be addressed; E-Mail: martyn.french@uwa.edu.au.

Received: 5 June 2013; in revised form: 11 July 2013 / Accepted: 23 July 2013 /

Published: 9 August 2013

\begin{abstract}
The development of vaccines to treat and prevent human immunodeficiency virus (HIV) infection has been hampered by an incomplete understanding of "protective" immune responses against HIV. Natural control of HIV-1 infection is associated with T-cell responses against HIV-1 Gag proteins, particularly $\mathrm{CD}^{+} \mathrm{T}$-cell responses restricted by "protective" HLA-B alleles, but other immune responses also contribute to immune control. These immune responses appear to include IgG antibodies to HIV-1 Gag proteins, interferon- $\alpha$-dependant natural killer (NK) cell responses and plasmacytoid dendritic cell (pDC) responses. Here, it is proposed that isotype diversification of $\mathrm{IgG}$ antibodies against HIV-1 Gag proteins, to include IgG2, as well as IgG3 and IgG1 antibodies, will broaden the function of the antibody response and facilitate accessory cell responses against HIV-1 by NK cells and pDCs. We suggest that this should be investigated as a vaccination strategy for HIV-1 infection.
\end{abstract}

Keywords: HIV; vaccine; HIV-1 Gag; IgG antibody diversification; IgG subclasses

\section{Introduction}

The development of human immunodeficiency virus (HIV) vaccines is a global health priority, particularly at a time when therapeutic vaccines are being considered as a component of a strategy for eradicating HIV infection [1]. However, the development of therapeutic HIV vaccines has been hampered by an incomplete understanding of protective immune responses that control HIV infection, 
as exemplified by the failure of multiple candidate vaccines [2]. Here, we propose the hypothesis that isotype diversification of IgG antibodies against HIV-1 Gag proteins contributes to the control of HIV-1 replication and review the supporting evidence for this hypothesis, including data from our own studies. Furthermore, we discuss how this information might be applied to therapeutic vaccination strategies for HIV-1 infection.

\section{Natural Control of HIV-1 Infection Is Associated with T-Cell Responses against HIV-1}

\section{Gag Proteins}

Approximately $1 \%$ of patients with HIV-1 infection control the infection without antiretroviral therapy (ART) and are referred to as controllers [3]. Intense analysis of controllers is being undertaken to define "protective" immune responses against HIV-1 proteins that might be enhanced by therapeutic vaccines. Studies of HIV-1 controllers suggest that natural immune control of HIV-1 correlates with $\mathrm{T}$-cell responses against viral proteins, particularly $\mathrm{CD} 8^{+} \mathrm{T}$-cell responses against proteins of the virus core encoded by Gag that are restricted by "protective" HLA-B alleles [4,5], "helped" by Th1 CD4 T-cells [6] and are "highly functional" [7]. Similarly, natural control of HIV-2 infection is also associated with high-magnitude polyfunctional Gag-specific $\mathrm{CD}^{+} \mathrm{T}$-cell responses [8]. Of note, resting $\mathrm{CD} 4^{+}$ T-cells "latently" infected with HIV-1 express Gag proteins on the cell surface more than other HIV proteins and are a potential target of immune responses against Gag proteins in patients receiving ART [9]. However, vaccine-induced $\mathrm{CD} 8^{+} \mathrm{T}$-cell responses against HIV-1 Gag proteins have not been associated with prevention or control of HIV-1 infection in randomised controlled clinical trials involving large numbers of patients $[2,10]$, though a clinical trial of an $\mathrm{Ad} 5 / \mathrm{Gag}$ vaccine as a therapeutic vaccine did demonstrate that vaccine-induced Gag-specific $\mathrm{CD} 4{ }^{+}$T-cells producing IFN- $\gamma$ correlated with control of HIV-1 replication [11].

\section{IgG Antibody Responses against HIV-1 Gag Proteins, Plasmacytoid Dendritic Cells and IFN- $\alpha$-Dependant Natural Killer Cell Responses May Also Contribute to Control of HIV-1 Infection}

Approximately one third of HIV-1 controllers do not exhibit evidence of HLA-B-restricted CD8 ${ }^{+}$T-cell responses against Gag proteins [12], suggesting that other immune responses also contribute to natural control of HIV-1 infection. At least 15 published studies undertaken between 1989 and 2000 in untreated HIV-1-infected adults and children who were not selected on the basis of a controller phenotype, demonstrated that progression of HIV-1 disease was slower in patients with higher serum levels and/or avidity of IgG antibodies to HIV-1 Gag proteins (p17, p24, p55) [13-29], suggesting that HIV-1 Gag proteins might be used as vaccine immunogens for eliciting antibodies to control HIV-1 infection. HIV-1 Gag proteins might have the particular advantage of exhibiting high intra-clade and inter-clade epitope conservation, at least for T-cell epitopes [30], and might thereby elicit broadly reactive antibodies.

In addition, an increasing amount of evidence indicates that natural control of HIV-1 infection is associated with responses by interferon (IFN)- $\alpha$-dependant natural killer (NK) cells [31] and plasmacytoid dendritic cells (pDCs) [32,33], which are the major producers of IFN- $\alpha$ [34]. Both NK cells and pDCs mediate innate immune responses against viruses [34,35], but both also function as accessory cells in $\mathrm{IgG}$ antibody responses, and therefore, their function might be enhanced by IgG antibodies induced by 
vaccines. Activation of both cell types induces a diverse anti-viral response that, in particular, includes lysis of virus-infected cells by NK cells and production of type I interferons by pDCs [34,35]. Plasmacytoid dendritic cells also function as antigen-presenting cells for T-cells [36-39], including cross-presentation to $\mathrm{CD}^{+} \mathrm{T}$-cells $[40,41]$, and regulate B-cell differentiation [42].

\section{The Role of Non-Neutralising Antibodies in the Control of HIV-1 Infection}

Non-neutralising antibodies mediate their effect by activating accessory cells, which also function as antigen-presenting cells and/or elicit innate immune responses. Activation of accessory cells by IgG non-neutralising antibodies is mediated by the Fc region of the antibody binding to Fcy receptors [43]. Antibody responses of this type elicited against HIV-1 proteins include antibody-dependant NK cell responses (often referred to as antibody-dependant cell-mediated cytotoxicity; ADCC) [44,45], antibody-dependant cell-mediated viral inhibition (ADCVI) [46] and phagocytic antibodies [47,48]. It is currently unclear to what extent these antibody responses are associated with control of HIV-1 infection. Thus, whilst ADCVI responses to whole virus may be associated with prevention of HIV infection after vaccination with recombinant gp120 [46], they are not associated with prevention of HIV-1 superinfection [49]. Similarly, long-term slow progression of HIV-1 infection has been associated with a wide breadth of antibody-dependant NK cell responses to regulatory/accessory proteins of HIV-1 [50], but immune escape from ADCC antibodies to envelope proteins is common [45].

\section{Diversification of IgG Antibody Responses against HIV-1 Gag Proteins May Broaden Fc Receptor Ligation and Accessory Cell Responses against HIV-1}

Antibody-induced activation of NK cells (including ADCC) results from ligation of Fc $\gamma$ RIIIa and is primarily mediated by monomeric or complexed antibodies of the IgG1 and IgG3 subclass, though complexed IgG2 and IgG4 antibodies can also bind to the 158V genotype of FcrRIIIa, which confers a higher affinity of Fc binding than the 158F genotype [51,52]. Plasmacytoid dendritic cells express the activatory receptor, Fc $\gamma$ RIIa, as well as small amounts of the inhibitory receptor, Fc $\gamma$ RIIb, in about $10 \%$ of healthy individuals, but not the activatory receptors, Fc $\gamma$ RI or Fc $\gamma$ RIIIa [53-57]. Fc $\gamma$ RIIa plays a dominant role in phagocytic antibody responses [58] and has been demonstrated to facilitate the phagocytosis of immune complexes containing "self" or viral nucleic acids by pDCs, resulting in sensing of those nucleic acids by toll-like receptors and pDC activation [54,55,59].

Studies in patients with HIV-1 infection have demonstrated that Fc $\gamma$ RIIa is the major FcR mediating phagocytosis of IgG antibodies complexed with gp120 [47]. Fc $\gamma$ RIIa may be particularly effective in phagocytosis-induced activation of myeloid cells by immune complexes in HIV-1 infection, because,

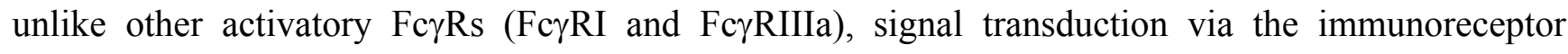
tyrosine-based activation motif (ITAM) of Fc $\gamma$ RIIa does not require the FcR common $\gamma$-chain adaptor molecule, which is depleted by HIV-1 infection [60]. Support for this is provided by the observation that the $131 \mathrm{H}$ genotype of the FcyRIIa gene, which confers higher affinity Fc binding to Fc $\gamma$ RIIa than the 131R genotype, is associated with slower progression of HIV-1 disease [61]. In contrast, the "high-affinity" $158 \mathrm{~V}$ genotype of Fc $\gamma$ RIIIa has been associated with an increased risk of acquiring HIV-1 infection [62,63] and also with an increased risk of HIV-1 disease progression [62], though the methods for analysing disease progression in that study are open to criticism. 


\section{Diversification of IgG Antibodies against HIV-1 Gag Proteins to Include IgG2 Antibodies May Facilitate Ligation of Fc $\gamma$ RIIa by Complexed Antibodies}

Studies of immune complex binding to Fc $\gamma$ RIIa in vitro demonstrate that all four subclasses of IgG are able to ligate the $131 \mathrm{H}$ genotype and, to a lesser extent, the 131R genotype of Fc $\gamma$ RIIa, especially in the form of large immune complexes [51,52]. Although the affinity of ligation of Fc $\gamma$ RIIa by IgG2 and IgG4 is less than that for IgG1 and IgG3, analyses of plasma immune complexes suggest that IgG2 antibodies play a particularly important role in the binding of immune complexes to FcyRIIa. IgG2 is the most abundant $\mathrm{IgG}$ isotype in plasma $\mathrm{IgG} / \mathrm{IgM}$ immune complexes of healthy individuals and a disease-associated increase in the ratio of IgG3 to IgG2 in the immune complexes is associated with decreased binding to Fc receptors on myeloid cells [64]. We have shown that IgG2 is much more abundant than IgG1 in FcyRIIa-binding immune complexes from plasma of healthy individuals and HIV controllers, but that failure to control HIV-1 replication is associated with more abundant IgG1 in the immune complexes [48].

It is well-established that IgG2 antibodies and FcyRIIa play an important role in phagocytic antibody responses against polysaccharide antigens of encapsulated bacteria $[65,66]$. We suggest that IgG2 antibodies also contribute to phagocytic IgG antibody responses against antigens of persistent viruses, such as HIV-1, mediated via immune complexes and FcyRIIa expressed by pDCs. Targeting of viral antigens to Fc $\gamma$ RIIa on BDCA- $3^{+}$dendritic cells by IgG antibodies has been proposed as a strategy for eliciting T-cell responses against viral antigens [67]. IgG2 is the only IgG subclass capable of covalent dimerization [68], which may enhance the function of this subclass of IgG antibody in phagocytosis and/or immune complex formation. In addition, IgG2 exhibits the highest degree of resistance to proteolytic degradation [69] and may also exhibit greater resistance than IgG1 to the adverse effects of deglycosylation of the Fc region on binding to FcrRIIa [70], though this was not confirmed in another study [52].

Support for our hypothesis that an IgG antibody response against HIV Gag proteins that has diversified to include IgG2 antibodies may be beneficial in the control of HIV-1 infection has been provided from studies in HIV-1 controllers or long-term non-progressors (LTNPs). Ngo-Giang-Huong et al. [71] examined plasma samples from 71 LTNPs, who had plasma HIV-1 RNA levels varying from $<20$ to 860,000 copies/mL and demonstrated that IgG2 antibodies to p55 and p24 were associated with lower plasma HIV-1 RNA levels. In contrast, plasma levels of IgG1 antibodies to these antigens did not correlate with HIV-1 RNA levels. We have examined plasma samples from $32 \mathrm{HIV}-1$ controllers, of whom 14 were elite controllers (plasma HIV RNA level $<50$ copies/mL), for IgG1 and IgG2 antibodies to HIV-1 proteins and shown that controllers had higher levels of IgG2 antibodies to Gag proteins than non-controllers and that this association was strongest in patients who did not carry the "protective" HLA-B57 allele [48]. In contrast, Banerjee et al. [72] examined serum from 16 HIV-1 controllers, of whom 13 had a plasma HIV-1 RNA level of $<75$ copies/mL, and demonstrated that although serum levels of total IgG and IgG1 antibodies to p24 were higher in HIV-1 controllers than patients with progressive HIV-1 disease, serum levels of IgG2 anti-p24 did not differ between HIV-1 controllers and patients with progressive HIV-1 disease. It is unclear why control of HIV-1 replication was associated with IgG2 antibodies against HIV-1 Gag proteins (p55 and/or p24) in two studies [48,71], but only with IgG1 antibodies to HIV-1 p24 in another [72]. Differences might reflect the use of Western blot assays and antigens from virus lysates in the studies by Ngo-Giang-Huong et al. [71] and French et al. [48], 
as opposed to ELISAs and recombinant HIV-1 proteins in the study by Banerjee et al. [72]. Furthermore, the study of HIV-1 controllers by Banerjee et al. [72] did not subgroup patients according to carriage of "protective" HLA-B alleles.

In summary, we suggest that diversification of an IgG antibody response against HIV-1 Gag proteins to include IgG2 antibodies, as well as IgG3 and IgG1 antibodies, may enhance the activation of accessory cell immune responses by NK cells and pDCs via ligation of both Fc $\gamma$ RIIIa and Fc $\gamma$ RIIa.

\section{Isotype Diversification of IgG Antibodies to Core or Capsid Proteins of Other Persistent Viruses Is Associated with Control of Infection}

Further support for our hypothesis that isotype diversification of IgG antibodies against HIV-1 Gag proteins is associated with control of HIV-1 infection is provided by evidence from patients infected by other persistent viruses. Data from patients with acute hepatitis C virus (HCV) infection suggests that $\operatorname{IgG2}$ antibodies to $\mathrm{HCV}$ core proteins might be associated with clearance of $\mathrm{HCV}$ infection. Zein et al. [73] reported that all of the four patients who spontaneously cleared HCV infection had IgG2 antibodies to HCV core proteins compared with only nine of 23 patients who did not clear the infection. Furthermore, the ratio of $\mathrm{IgG} 2 / \mathrm{IgG} 1 \mathrm{HCV}$ core-specific antibody titres was $>1$ in three of the four patients. In addition, studies in patients with human papillomavirus (HPV) infection demonstrated that IgG2 antibodies to capsid proteins were associated with protection from HPV disease using an ELISA and virus-like particles as antigens [74], though IgG2 antibodies could not be detected at all in another study when capsid proteins were used as antigens [75].

\section{Regulation of IgG Antibody Isotype Diversification and the Effect of HIV Infection}

Isotype diversification of $\mathrm{IgG}$ antibody responses occurs during the process of B-cell differentiation and maturation of the antibody response, which occurs in germinal centres of lymphoid tissue follicles following the interaction of naive B-cells with follicular dendritic cells and follicular-helper T-cells ( $\mathrm{T}_{\mathrm{FH}}$-cells) [76]. Immunoglobulin isotype switching during B-cell differentiation occurs through class switch recombination of immunoglobulin heavy chain genes, with switching to IgG2 and IgG4 occurring "downstream" of IgG3 and IgG1 [77], and results in broadening of IgG antibody function mediated by the Fc region (Table 1). Together, $\operatorname{IgG} 1$ and $\mathrm{IgG} 2$ comprise about $90 \%$ of serum $\operatorname{IgG}[78]$ and, therefore, exert the largest functional effect on an IgG antibody response.

Regulation of immunoglobulin isotype switching is mediated primarily by molecules expressed on, or produced by, $\mathrm{T}_{\mathrm{FH}^{-}}$-ells [76]. The most important are the co-stimulatory molecules, $\mathrm{CD} 40$ ligand and inducible co-stimulator (ICOS), as exemplified by the association of immunoglobulin deficiency with deficiency of these molecules [79,80], and the cytokines, IL-4, IL-10 and IL-21, as exemplified by the restoration of immunoglobulin production by B-cells from patients with IgA deficiency or common variable immunodeficiency disorder when cultured with these cytokines [81-83]. The co-inhibitory molecule programmed death (PD)- 1 is also highly expressed by $\mathrm{T}_{\mathrm{FH}}$-cells, and ligation by the ligand PD-L1 has been shown to down-regulate ICOS expression and IL-21 production and possibly contribute to $\mathrm{T}_{\mathrm{FH}}$-cell dysfunction caused by HIV infection [84]. Pro-inflammatory cytokines, such IL-2, IL-6 and IFN- $\gamma$, also contribute to isotype diversification of IgG antibodies, but primarily by enhancing production of IgG subclasses rather than initiating isotype switching [85-89] (Figure 1). 
Table 1. Isotype diversification of IgG antibodies leads to broadening of the function of an IgG antibody response.

\begin{tabular}{|c|c|c|}
\hline IgG3 & IgG2 & IgG4 \\
\hline $\begin{array}{l}\text { Ligation of all Fc receptors, } \\
\text { including Fc } \gamma \mathrm{RI} \text { in monomeric } \\
\text { form }(\mathrm{IgG} 3>\operatorname{IgG} 1)\end{array}$ & $\begin{array}{l}\text { Restricted ligation of Fc receptors } \\
\text { and only when complexed, } \\
\text { particularly large complexes }\end{array}$ & $\begin{array}{l}\text { Restricted ligation of Fc receptors } \\
\text { and only when complexed, } \\
\text { particularly large complexes }\end{array}$ \\
\hline \multirow{5}{*}{$\begin{array}{l}\text { Potent complement activation } \\
\text { through the classical pathway } \\
(\mathrm{IgG} 3>\operatorname{IgG} 1)\end{array}$} & Weak complement activation & No complement activation \\
\hline & $\begin{array}{l}\text { Most resistant of all IgG isotypes } \\
\text { to proteolytic degradation }\end{array}$ & $\begin{array}{l}\text { Produced after chronic immune } \\
\text { stimulation, particularly } \\
\text { parasite infections }\end{array}$ \\
\hline & $\begin{array}{l}\text { Predominant IgG subclass in } \\
\text { plasma IgM-IgG complexes }\end{array}$ & Regulated similarly to IgE \\
\hline & $\begin{array}{l}\text { Only IgG subclass to undergo } \\
\text { covalent dimerization }\end{array}$ & May form bispecific antibodies \\
\hline & $\begin{array}{l}\text { Predominant IgG subclass in } \\
\text { phagocytic antibodies to } \\
\text { polysaccharide antigens }\end{array}$ & \\
\hline
\end{tabular}

Figure 1. Isotype diversification of an IgG antibody response. IgG antibody isotype switching during B-cell differentiation in germinal centres results from class switch recombination of immunoglobulin heavy chain genes from "downstream" (IgG3 and IgG1) to "upstream" (IgG2 and IgG4) isotypes regulated by co-stimulatory molecules (CD40L and inducible co-stimulator (ICOS)) and cytokines (IL-4, IL-10 and IL-21). Pro-inflammatory cytokines (IL-2, IL-6 and IFN- $\gamma$ ) enhance immunoglobulin production with IFN- $\gamma$ particularly increasing IgG2 production. $\mathrm{CD}^{+} \mathrm{T}$-cell production of both IL-21 and IFN- $\gamma$ is impaired by HIV infection.

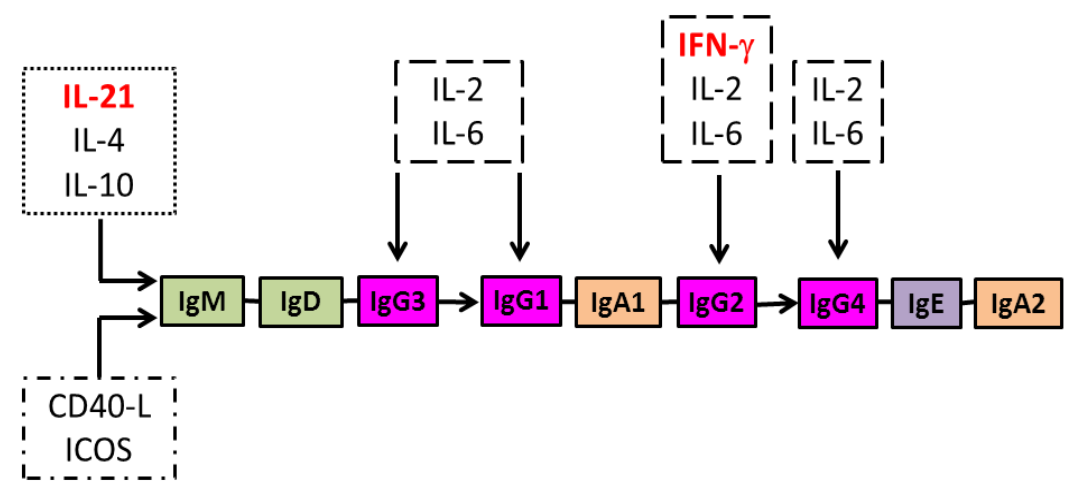

While B-cell activation and increased production of total IgG is characteristic of HIV infection, driven to a large degree by pro-inflammatory cytokines [90], IgG2 deficiency is common in HIV patients [47,91], and IgG2 and IgA are less abundant in lymph node germinal centres of HIV patients than controls [92]. Indeed, serum levels of the "upstream" isotypes, IgG3 and IgG1, are increased, whereas serum levels of the "downstream" isotypes, IgG2 and $\mathrm{IgG} 4$, are decreased in HIV patients [90,93], suggesting an acquired disorder of B-cell differentiation and isotype diversification similar to that in patients with primary antibody deficiency disorders [94]. 
Data from studies of cytokine regulation of IgG subclass production by B-cells $[85,86,88]$ and of patients with IgG2 deficiency [89] indicate that IFN- $\gamma$ plays a particularly important role in the production of IgG2. Decreased IgG2 production in HIV patients may therefore be a consequence of both impaired B-cell isotype switching associated with $\mathrm{T}_{\mathrm{FH}}$-cell dysfunction $[84,95]$ and impaired IFN- $\gamma$ production that characterises HIV-induced immunodeficiency, but is preserved in HIV controllers [6]. We provided evidence in support of this proposal from a study of antibody responses to HIV p24 in ART-treated HIV patients enrolled into a clinical trial of a recombinant DNA vaccine encoding a fowlpox virus vector, HIV Gag-Pol and IFN- $\gamma$ [96]. Although the number of patients was small, this study provided evidence that the vaccine construct containing the gene for IFN- $\gamma$ increased IgG antibodies to HIV p24, including IgG2 antibodies, which were associated with better control of HIV replication after ART was ceased in patients who possessed the $131 \mathrm{H}$ genotype of Fc $\gamma \mathrm{RIIa}$, which results in the highest affinity binding of IgG2 antibodies to that receptor.

It is notable that lymph node $\mathrm{T}_{\mathrm{FH}}$-cells of patients with HIV-1 infection exhibit greater reactivity with Gag proteins than Env proteins [97]. Dysfunction of $\mathrm{T}_{\mathrm{FH}}$-cells associated with HIV-1 infection [84,95,97] may therefore contribute to limited isotype diversification of IgG antibodies against HIV-1 Gag proteins.

\section{Potential Strategies for Enhancing Isotype Diversification of IgG Antibodies to HIV-1 Gag Proteins}

Therapeutic modulation of the isotype of vaccine-induced IgG antibodies is not an established procedure in humans, but has been achieved in dogs with a saponin-adjuvanted Leishmania vaccine [98]. Preliminary data from patients with HIV-1 infection suggest that IFN- $\gamma$ might enhance vaccine-induced IgG2 antibodies to HIV-1 Gag proteins [96], and this potential approach to therapeutic vaccination should be considered further. Finally, inhibition of immune activation in HIV-1 patients by PD-1 blockade might also have beneficial effects on $\mathrm{T}_{\mathrm{FH}}$-cell function [84] and antibody responses [99], and examination of IgG antibody isotype diversification might be examined in clinical trials of therapies that block the PD-1/PD-L1 pathway.

\section{Conclusions}

We propose that enhancing isotype diversification of IgG antibody responses against HIV-1 Gag proteins during vaccination, to include IgG2, as well as IgG3 and IgG1 antibodies, may result in an IgG antibody response that facilitates the accessory cell responses of NK cells and pDCs to elicit both ADCC responses by NK cells, as well as phagocytosis of complexed antibody by pDCs and a pDC-dependant antiviral response (Figure 2). Further experimental evidence is required to strengthen our hypothesis. In particular, studies are needed to establish that IgG2 antibodies inhibit HIV-1 replication and are not just a marker of Th1 responses. However, at a time when new approaches to the development of HIV vaccines are needed [2], we suggest that consideration should be given to vaccination strategies that will enhance isotype diversification of IgG antibodies against HIV-1 Gag proteins. 
Figure 2. A diagrammatic representation of how isotype diversification of $\operatorname{IgG}$ antibodies against HIV-1 Gag proteins might enhance anti-viral accessory cell responses against HIV-1 infection. It is proposed that IgG antibodies bind to HIV-1 Gag proteins expressed on the surface of cells infected by HIV-1, including resting $\mathrm{CD}^{+}{ }^{+}$T-cells [9]. Activation of natural killer (NK) cells is elicited by "downstream" IgG isotypes (IgG3 and IgG1) via Fc $\gamma$ RIIIa. "Upstream" IgG isotypes (IgG2 and possibly IgG4) may also contribute to NK cell activation by ligating FcyRIIIa, particularly in individuals carrying the $158 \mathrm{~V}$ genotype. However, it is proposed that multimeric $\mathrm{IgG} 2$ antibodies primarily broaden the function of the antibody response by enhancing phagocytic activity against Gag proteins associated with HIV-1 RNA, as a consequence of the functional characteristics of IgG2 (see Table 1), which activates plasmacytoid dendritic cells (pDCs) via Fc $\gamma$ RIIa. Activation of pDCs leads to the production of IFN- $\alpha$, which facilitates NK cell responses and induces the production of interferon-stimulated genes (ISGs) and to antigen presentation and/or stimulation of B- and T-cells (see text). HIV-1 infection impairs diversification of an $\operatorname{IgG}$ antibody response to "downstream" isotypes.

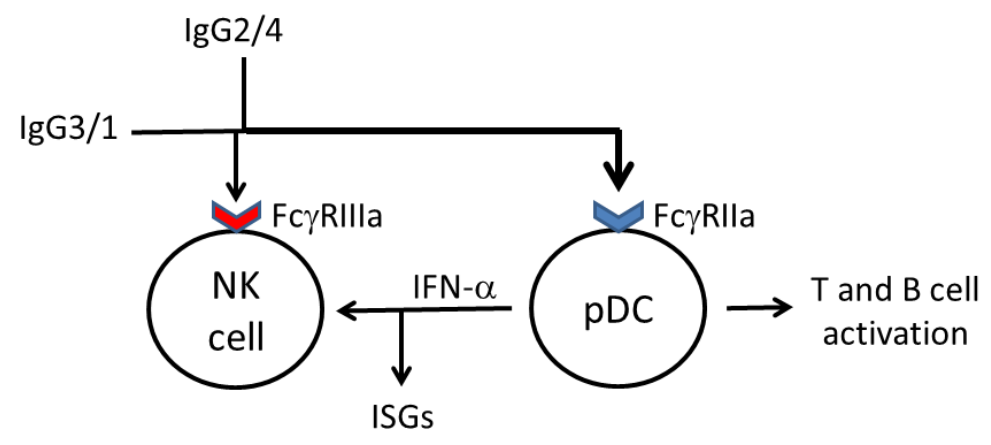

\section{Acknowledgments}

We acknowledge the financial support of the National Health and Medical Research Council of Australia (grant 510448) and The Medical Research Foundation of Royal Perth Hospital.

\section{Conflict of Interest}

The authors declare no conflict of interest.

\section{References}

1. Shan, L.; Deng, K.; Shroff, N.S.; Durand, C.M.; Rabi, S.A.; Yang, H.C.; Zhang, H.; Margolick, J.B.; Blankson, J.N.; Siliciano, R.F. Stimulation of HIV-1-specific cytolytic T lymphocytes facilitates elimination of latent viral reservoir after virus reactivation. Immunity 2012, 36, 491-501.

2. Cohen, J. More woes for struggling HIV vaccine field. Science 2013, 340, 667.

3. Deeks, S.G.; Walker, B.D. Human immunodeficiency virus controllers: Mechanisms of durable virus control in the absence of antiretroviral therapy. Immunity 2007, 27, 406-416. 
4. Saez-Cirion, A.; Sinet, M.; Shin, S.Y.; Urrutia, A.; Versmisse, P.; Lacabaratz, C.; Boufassa, F.; Avettand-Fenoel, V.; Rouzioux, C.; Delfraissy, J.F.; et al. Heterogeneity in HIV suppression by CD8 T-cells from HIV controllers: Association with Gag-specific CD8 T-cell responses. J. Immunol. 2009, 182, 7828-7837.

5. Ferre, A.L.; Lemongello, D.; Hunt, P.W.; Morris, M.M.; Garcia, J.C.; Pollard, R.B.; Yee, H.F., Jr.; Martin, J.N.; Deeks, S.G.; Shacklett, B.L. Immunodominant HIV-specific CD ${ }^{+}$T-cell responses are common to blood and gastrointestinal mucosa, and Gag-specific responses dominate in rectal mucosa of HIV controllers. J. Virol. 2010, 84, 10354-10365.

6. Vingert, B.; Benati, D.; Lambotte, O.; de Truchis, P.; Slama, L.; Jeannin, P.; Galperin, M.; Perez-Patrigeon, S.; Boufassa, F.; Kwok, W.W.; et al. HIV controllers maintain a population of highly efficient Th1 effector cells in contrast to patients treated in the long term. J. Virol. 2012, 86, 10661-10674.

7. Techakriengkrai, N.; Tansiri, Y.; Hansasuta, P. Poor HIV control in HLA-B*27 and B*57/58 noncontrollers is associated with limited number of polyfunctional Gag p24-specific CD $8^{+} \mathrm{T}$-cells. AIDS 2013, 27, 17-27.

8. De Silva, T.I.; Peng, Y.; Leligdowicz, A.; Zaidi, I.; Li, L.; Griffin, H.; Blais, M.E.; Vincent, T.; Saraiva, M.; Yindom, L.M.; et al. Correlates of T-cell mediated viral control and phenotype of CD8 ${ }^{+}$ T-cells in HIV-2, a naturally contained human retroviral infection. Blood 2013, 121, 4330-4339.

9. Pace, M.J.; Graf, E.H.; Agosto, L.M.; Mexas, A.M.; Male, F.; Brady, T.; Bushman, F.D.; O'Doherty, U. Directly infected resting CD4 ${ }^{+}$T-cells can produce HIV Gag without spreading infection in a model of HIV latency. PLoS Pathog. 2012, 8, e1002818.

10. McElrath, M.J.; de Rosa, S.C.; Moodie, Z.; Dubey, S.; Kierstead, L.; Janes, H.; Defawe, O.D.; Carter, D.K.; Hural, J.; Akondy, R.; et al. HIV-1 vaccine-induced immunity in the test-of-concept Step Study: A case-cohort analysis. Lancet 2008, 372, 1894-1905.

11. Schooley, R.T.; Spritzler, J.; Wang, H.; Lederman, M.M.; Havlir, D.; Kuritzkes, D.R.; Pollard, R.; Battaglia, C.; Robertson, M.; Mehrotra, D.; et al. AIDS clinical trials group 5197: A placebocontrolled trial of immunization of HIV-1-infected persons with a replication-deficient adenovirus type 5 vaccine expressing the HIV-1 core protein. J. Infect. Dis. 2010, 202, 705-716.

12. Emu, B.; Sinclair, E.; Hatano, H.; Ferre, A.; Shacklett, B.; Martin, J.N.; McCune, J.M.; Deeks, S.G. HLA class I-restricted T-cell responses may contribute to the control of human immunodeficiency virus infection, but such responses are not always necessary for long-term virus control. J. Virol. 2008, 82, 5398-5407.

13. Schmidt, G.; Amiraian, K.; Frey, H.; Wethers, J.; Stevens, R.W.; Berns, D.S. Monitoring human immunodeficiency virus type 1 -infected patients by ratio of antibodies to gp41 and p24. J. Clin. Microbiol. 1989, 27, 843-848.

14. Fernandez-Cruz, E.; Desco, M.; Garcia-Montes, M.; Longo, N.; Gonzalez, B.; Zabay, J.M. Immunological and serological markers predictive of progression to AIDS in a cohort of HIV-infected drug users. AIDS 1990, 4, 987-994.

15. Mertens, T.; Ramon, A.; Kruppenbacher, J.P.; Heitmann, K.; Pika, U.; Leyssens, N.; Lievens, M. Virological examinations of patients with AIDS-related complex/Walter-Reed 5 enrolled in a double-blind placebo-controlled study with intravenous gammaglobulin administration. Vox Sang. 1990, 59, 21-29. 
16. Allain, J.P.; Laurian, Y.; Einstein, M.H.; Braun, B.P.; Delaney, S.R.; Stephens, J.E.; Daluga, C.K.; Dahlen, S.J.; Knigge, K.M. Monitoring of specific antibodies to human immunodeficiency virus structural proteins: Clinical significance. Blood 1991, 77, 1118-1123.

17. Cheingsong-Popov, R.; Panagiotidi, C.; Bowcock, S.; Aronstam, A.; Wadsworth, J.; Weber, J. Relation between humoral responses to HIV gag and env proteins at seroconversion and clinical outcome of HIV infection. Br. Med. J. 1991, 302, 23-26.

18. Sheppard, H.W.; Ascher, M.S.; McRae, B.; Anderson, R.E.; Lang, W.; Allain, J.P. The initial immune response to HIV and immune system activation determine the outcome of HIV disease. J. Acquir. Immune Defic. Syndr. 1991, 4, 704-712.

19. Farzadegan, H.; Chmiel, J.S.; Odaka, N.; Ward, L.; Poggensee, L.; Saah, A.; Phair, J.P. Association of antibody to human immunodeficiency virus type 1 core protein (p24), CD4 ${ }^{+}$lymphocyte number, and AIDS-free time. J. Infect. Dis. 1992, 166, 1217-1222.

20. Chargelegue, D.; Colvin, B.T.; O’Toole, C.M. A 7-year analysis of anti-Gag (p17 and p24) antibodies in HIV-1-seropositive patients with haemophilia: Immunoglobulin G titre and avidity are early predictors of clinical course. AIDS 1993, 7, S87-S90.

21. Chargelegue, D.; O'Toole, C.M.; Colvin, B.T. A longitudinal study of the IgG antibody response to HIV-1 p17 gag protein in HIV $-1^{+}$patients with haemophilia: Titre and avidity. Clin. Exp. Immunol. 1993, 93, 331-336.

22. Zwart, G.; van der Hoek, L.; Valk, M.; Cornelissen, M.T.; Baan, E.; Dekker, J.; Koot, M.; Kuiken, C.L.; Goudsmit, J. Antibody responses to HIV-1 envelope and gag epitopes in HIV-1 seroconverters with rapid versus slow disease progression. Virology 1994, 201, 285-293.

23. Chargelegue, D.; Stanley, C.M.; O’Toole, C.M.; Colvin, B.T.; Steward, M.W. The affinity of IgG antibodies to gag p24 and p17 in HIV-1-infected patients correlates with disease progression. Clin. Exp. Immunol. 1995, 99, 175-181.

24. Hogervorst, E.; Jurriaans, S.; de Wolf, F.; van Wijk, A.; Wiersma, A.; Valk, M.; Roos, M.; van Gemen, B.; Coutinho, R.; Miedema, F.; et al. Predictors for non- and slow progression in human immunodeficiency virus (HIV) type 1 infection: Low viral RNA copy numbers in serum and maintenance of high HIV-1 p24-specific but not V3-specific antibody levels. J. Infect. Dis. 1995, 171, 811-821.

25. Morand-Joubert, L.; Bludau, H.; Lerable, J.; Petit, J.C.; Lefrere, J.J. Serum anti-p24 antibody concentration has a predictive value on the decrease of CD4 lymphocyte count higher than acid-dissociated p24 antigen. J. Med. Virol. 1995, 47, 87-91.

26. Garland, F.C.; Garland, C.F.; Gorham, E.D.; Brodine, S.K. Western blot banding patterns of HIV rapid progressors in the U.S. Navy Seropositive Cohort: Implications for vaccine development. Navy Retroviral Working Group. Ann. Epidemiol. 1996, 6, 341-347.

27. Thomas, H.I.; Wilson, S.; O’Toole, C.M.; Lister, C.M.; Saeed, A.M.; Watkins, R.P.; Morgan-Capner, P. Differential maturation of avidity of IgG antibodies to gp41, p24 and p17 following infection with HIV-1. Clin. Exp. Immunol. 1996, 103, 185-191.

28. Mofenson, L.M.; Harris, D.R.; Rich, K.; Meyer, W.A., 3rd; Read, J.S.; Moye, J., Jr.; Nugent, R.P.; Korelitz, J.; Bethel, J.; Pahwa, S. Serum HIV-1 p24 antibody, HIV-1 RNA copy number and CD4 lymphocyte percentage are independently associated with risk of mortality in HIV-1-infected children. AIDS 1999, 13, 31-39. 
29. Read, J.S.; Rich, K.C.; Korelitz, J.J.; Mofenson, L.M.; Harris, R.; Moye, J.H., Jr.; Meyer, W.A., 3rd.; Pahwa, S.G.; Bethel, J.W.; Nugent, R.P. Quantification of human immunodeficiency virus type 1 p24 antigen and antibody rivals human immunodeficiency virus type 1 RNA and CD4 ${ }^{+}$enumeration for prognosis. Pediatr. Infect. Dis. J. 2000, 19, 544-551.

30. Malhotra, U.; Nolin, J.; Mullins, J.I.; McElrath, M.J. Comprehensive epitope analysis of cross-clade Gag-specific T-cell responses in individuals with early HIV-1 infection in the U.S. epidemic. Vaccine 2007, 25, 381-90.

31. Tomescu, C.; Duh, F.M.; Hoh, R.; Viviani, A.; Harvill, K.; Martin, M.P.; Carrington, M.; Deeks, S.G.; Montaner, L.J. Impact of protective killer inhibitory receptor/human leukocyte antigen genotypes on natural killer cell and T-cell function in HIV-1-infected controllers. AIDS 2012, 26, 1869-1878.

32. Barblu, L.; Machmach, K.; Gras, C.; Delfraissy, J.F.; Boufassa, F.; Leal, M.; Ruiz-Mateos, E.; Lambotte, O.; Herbeuval, J.P. Plasmacytoid dendritic cells (pDCs) from HIV controllers produce interferon-alpha and differentiate into functional killer pDCs under HIV activation. J. Infect. Dis. 2012, 206, 790-801.

33. Machmach, K.; Leal, M.; Gras, C.; Viciana, P.; Genebat, M.; Franco, E.; Boufassa, F.; Lambotte, O.; Herbeuval, J.P.; Ruiz-Mateos, E. Plasmacytoid dendritic cells reduce HIV production in elite controllers. J. Virol. 2012, 86, 4245-4252.

34. Lande, R.; Gilliet, M. Plasmacytoid dendritic cells: Key players in the initiation and regulation of immune responses. Ann. NY Acad. Sci. 2010, 1183, 89-103.

35. Jost, S.; Altfeld, M. Control of human viral infections by natural killer cells. Annu. Rev. Immunol. 2013, 31, 163-194.

36. Jaehn, P.S.; Zaenker, K.S.; Schmitz, J.; Dzionek, A. Functional dichotomy of plasmacytoid dendritic cells: Antigen-specific activation of T-cells versus production of type I interferon. Eur. J. Immunol. 2008, 38, 1822-1832.

37. Villadangos, J.A.; Young, L. Antigen-presentation properties of plasmacytoid dendritic cells. Immunity 2008, 29, 352-361.

38. Tel, J.; Lambeck, A.J.; Cruz, L.J.; Tacken, P.J.; de Vries, I.J.; Figdor, C.G. Human plasmacytoid dendritic cells phagocytose, process, and present exogenous particulate antigen. J. Immunol. 2010, 184, 4276-4283.

39. Tel, J.; Smits, E.L.; Anguille, S.; Joshi, R.N.; Figdor, C.G.; de Vries, I.J. Human plasmacytoid dendritic cells are equipped with antigen-presenting and tumoricidal capacities. Blood 2012, 120, 3936-3944.

40. Di Pucchio, T.; Chatterjee, B.; Smed-Sorensen, A.; Clayton, S.; Palazzo, A.; Montes, M.; Xue, Y.; Mellman, I.; Banchereau, J.; Connolly, J.E. Direct proteasome-independent cross-presentation of viral antigen by plasmacytoid dendritic cells on major histocompatibility complex class I. Nat. Immunol. 2008, 9, 551-557.

41. Tel, J.; Schreibelt, G.; Sittig, S.P.; Mathan, T.S.; Buschow, S.I.; Cruz, L.J.; Lambeck, A.J.; Figdor, C.G.; de Vries, I.J. Human plasmacytoid dendritic cells efficiently cross-present exogenous Ags to $\mathrm{CD}^{+} \mathrm{T}$-cells despite lower Ag uptake than myeloid dendritic cell subsets. Blood 2013, 121, 459-467.

42. Shaw, J.; Wang, Y.H.; Ito, T.; Arima, K.; Liu, Y.J. Plasmacytoid dendritic cells regulate B-cell growth and differentiation via CD70. Blood 2010, 115, 3051-3057. 
43. Forthal, D.N.; Moog, C. Fc receptor-mediated antiviral antibodies. Curr. Opin. HIV AIDS 2009, 4, 388-393.

44. Stratov, I.; Chung, A.; Kent, S.J. Robust NK cell-mediated human immunodeficiency virus (HIV)specific antibody-dependent responses in HIV-infected subjects. J. Virol. 2008, 82, 5450-5459.

45. Chung, A.W.; Isitman, G.; Navis, M.; Kramski, M.; Center, R.J.; Kent, S.J.; Stratov, I. Immune escape from HIV-specific antibody-dependent cellular cytotoxicity (ADCC) pressure. Proc. Natl. Acad. Sci. USA 2011, 108, 7505-7510.

46. Forthal, D.N.; Gilbert, P.B.; Landucci, G.; Phan, T. Recombinant gp120 vaccine-induced antibodies inhibit clinical strains of HIV-1 in the presence of Fc receptor-bearing effector cells and correlate inversely with HIV infection rate. J. Immunol. 2007, 178, 6596-6603.

47. Ackerman, M.E.; Dugast, A.S.; McAndrew, E.G.; Tsoukas, S.; Licht, A.F.; Irvine, D.J.; Alter, G. Enhanced phagocytic activity of HIV-specific antibodies correlates with natural production of immunoglobulins with skewed affinity for Fc $\gamma$ R2a and Fc $\gamma$ R2b. J. Virol. 2013, 87, 5468-5476.

48. French, M.A.; Center, R.J.; Wilson, K.M.; Fleyfel, I.; Fernandez, S.; Schorcht, A.; Stratov, I.; Kramski, M.; Kent, S.J.; Kelleher, A.D. Isotype-switched immunoglobulin G antibodies to HIV Gag proteins may provide alternative or additional immune responses to "protective" human leukocyte antigen-B alleles in HIV controllers. AIDS 2013, 27, 519-528.

49. Forthal, D.N.; Landucci, G.; Chohan, B.; Richardson, B.A.; McClelland, R.S.; Jaoko, W.; Blish, C.; Overbaugh, J. Antibody-dependent cell-mediated virus inhibition antibody activity does not correlate with risk of HIV-1 superinfection. J. Acquir. Immune Defic. Syndr. 2013, 63, 31-33.

50. Wren, L.H.; Chung, A.W.; Isitman, G.; Kelleher, A.D.; Parsons, M.S.; Amin, J.; Cooper, D.A.; Stratov, I.; Navis, M.; Kent, S.J. Specific antibody-dependent cellular cytotoxicity responses associated with slow progression of HIV infection. Immunology 2013, 138, 116-123.

51. Bruhns, P.; Iannascoli, B.; England, P.; Mancardi, D.A.; Fernandez, N.; Jorieux, S.; Daeron, M. Specificity and affinity of human Fc receptors and their polymorphic variants for human IgG subclasses. Blood 2009, 113, 3716-3725.

52. Lux, A.; Yu, X.; Scanlan, C.N.; Nimmerjahn, F. Impact of immune complex size and glycosylation on IgG binding to human Fc $\gamma$ Rs. J. Immunol. 2013, 190, 4315-4323.

53. Bave, U.; Magnusson, M.; Eloranta, M.L.; Perers, A.; Alm, G.V.; Ronnblom, L. Fc $\gamma$ RIIa is expressed on natural IFN- $\alpha$-producing cells (plasmacytoid dendritic cells) and is required for the IFN- $\alpha$ production induced by apoptotic cells combined with lupus IgG. J. Immunol. 2003, 171, 3296-3302.

54. Means, T.K.; Latz, E.; Hayashi, F.; Murali, M.R.; Golenbock, D.T.; Luster, A.D. Human lupus autoantibody-DNA complexes activate DCs through cooperation of CD32 and TLR9. J. Clin. Invest. 2005, 115, 407-417.

55. Lovgren, T.; Eloranta, M.L.; Kastner, B.; Wahren-Herlenius, M.; Alm, G.V.; Ronnblom, L. Induction of interferon-alpha by immune complexes or liposomes containing systemic lupus erythematosus autoantigen- and Sjogren's syndrome autoantigen-associated RNA. Arthritis Rheum. 2006, 54, 1917-1927.

56. Su, K.; Yang, H.; Li, X.; Gibson, A.W.; Cafardi, J.M.; Zhou, T.; Edberg, J.C.; Kimberly, R.P. Expression profile of Fc $\gamma \mathrm{RIIb}$ on leukocytes and its dysregulation in systemic lupus erythematosus. J. Immunol. 2007, 178, 3272-3280. 
57. Dugast, A.S.; Tonelli, A.; Berger, C.T.; Ackerman, M.E.; Sciaranghella, G.; Liu, Q.; Sips, M.; Toth, I.; Piechocka-Trocha, A.; Ghebremichael, M.; et al. Decreased Fc receptor expression on innate immune cells is associated with impaired antibody-mediated cellular phagocytic activity in chronically HIV-1 infected individuals. Virology 2011, 415, 160-167.

58. Nimmerjahn, F.; Ravetch, J.V. Fc $\gamma$ receptors as regulators of immune responses. Nat. Rev. Immunol. 2008, 8, 34-47.

59. Wang, J.P.; Asher, D.R.; Chan, M.; Kurt-Jones, E.A.; Finberg, R.W. Cutting Edge: Antibodymediated TLR7-dependent recognition of viral RNA. J. Immunol. 2007, 178, 3363-3367.

60. Leeansyah, E.; Wines, B.D.; Crowe, S.M.; Jaworowski, A. The mechanism underlying defective $\mathrm{Fc} \gamma$ receptor-mediated phagocytosis by HIV-1-infected human monocyte-derived macrophages. J. Immunol. 2007, 178, 1096-1104.

61. Forthal, D.N.; Landucci, G.; Bream, J.; Jacobson, L.P.; Phan, T.B.; Montoya, B. FcrRIIa genotype predicts progression of HIV infection. J. Immunol. 2007, 179, 7916-7923.

62. Poonia, B.; Kijak, G.H.; Pauza, C.D. High affinity allele for the gene of FCGR3A is risk factor for HIV infection and progression. PLoS One 2010, 5, e15562.

63. Forthal, D.N.; Gabriel, E.E.; Wang, A.; Landucci, G.; Phan, T.B. Association of Fe $\gamma$ receptor IIIa genotype with the rate of HIV infection after gp120 vaccination. Blood 2012, 120, 2836-2842.

64. Stahl, D.; Sibrowski, W. IgG2 containing IgM-IgG immune complexes predominate in normal human plasma, but not in plasma of patients with warm autoimmune haemolytic anaemia. Eur. J. Haematol. 2006, 77, 191-202.

65. Vitharsson, G.; Jonsdottir, I.; Jonsson, S.; Valdimarsson, H. Opsonization and antibodies to capsular and cell wall polysaccharides of Streptococcus pneumoniae. J. Infect. Dis. 1994, 170, 592-599.

66. Rodriguez, M.E.; van der Pol, W.L.; Sanders, L.A.; van de Winkel, J.G. Crucial role of FcrRIIa (CD32) in assessment of functional anti-Streptococcus pneumoniae antibody activity in human sera. J. Infect. Dis. 1999, 179, 423-433.

67. Flinsenberg, T.W.; Compeer, E.B.; Koning, D.; Klein, M.; Amelung, F.J.; van Baarle, D.; Boelens, J.J.; Boes, M. Fc $\gamma$ receptor antigen targeting potentiates cross-presentation by human blood and lymphoid tissue BDCA-3 ${ }^{+}$dendritic cells. Blood 2012, 120, 5163-5172.

68. Yoo, E.M.; Wims, L.A.; Chan, L.A.; Morrison, S.L. Human IgG2 can form covalent dimers. J. Immunol. 2003, 170, 3134-3138.

69. Meulenbroek, A.J. Human IgG Subclasses: Useful Diagnostic Markers for Immunocompetence, 3rd ed; Sanquin: Amsterdam, The Netherlands, 2008; pp. 11-14.

70. Allhorn, M.; Olin, A.I.; Nimmerjahn, F.; Collin, M. Human IgG/Fc $\gamma$ R interactions are modulated by streptococcal IgG glycan hydrolysis. PLoS One 2008, 3, e1413.

71. Ngo-Giang-Huong, N.; Candotti, D.; Goubar, A.; Autran, B.; Maynart, M.; Sicard, D.; Clauvel, J.P.; Agut, H.; Costagliola, D.; Rouzioux, C. HIV type 1-specific IgG2 antibodies: Markers of helper T-cell type 1 response and prognostic marker of long-term nonprogression. AIDS Res. Hum. Retroviruses 2001, 17, 1435-1446.

72. Banerjee, K.; Klasse, P.J.; Sanders, R.W.; Pereyra, F.; Michael, E.; Lu, M.; Walker, B.D.; Moore, J.P. IgG subclass profiles in infected HIV type 1 controllers and chronic progressors and in uninfected recipients of Env vaccines. AIDS Res. Hum. Retroviruses 2010, 26, 445-458. 
73. Zein, N.N.; Li, H.; Persing, D.H. Humoral immunity in acute and chronic hepatitis C infection. Gastroenterology 1999, 117, 510.

74. Matsumoto, K.; Yoshikawa, H.; Yasugi, T.; Nakagawa, S.; Kawana, K.; Nozawa, S.; Hoshiai, H.; Shiromizu, K.; Kanda, T.; Taketani, Y. Balance of IgG subclasses toward human papillomavirus type 16 (HPV16) L1-capsids is a possible predictor for the regression of HPV16-positive cervical intraepithelial neoplasia. Biochem. Biophys. Res. Commun. 1999, 258, 128-131.

75. Wang, Z.H.; Kjellberg, L.; Abdalla, H.; Wiklund, F.; Eklund, C.; Knekt, P.; Lehtinen, M.; Kallings, I.; Lenner, P.; Hallmans, G.; et al. Type specificity and significance of different isotypes of serum antibodies to human papillomavirus capsids. J. Infect. Dis. 2000, 181, 456-462.

76. Ma, C.S.; Deenick, E.K.; Batten, M.; Tangye, S.G. The origins, function, and regulation of T follicular helper cells. J. Exp. Med. 2012, 209, 1241-1253.

77. Pan-Hammarstrom, Q.; Zhao, Y.; Hammarstrom, L. Class switch recombination: A comparison between mouse and human. Adv. Immunol. 2007, 93, 1-61.

78. French, M. Serum IgG subclasses in normal adults. Monogr. Allergy 1986, 19, 100-107.

79. Ferrari, S.; Plebani, A. Cross-talk between CD40 and CD40L: Lessons from primary immune deficiencies. Curr. Opin. Allergy Clin. Immunol. 2002, 2, 489-494.

80. Warnatz, K.; Bossaller, L.; Salzer, U.; Skrabl-Baumgartner, A.; Schwinger, W.; van der Burg, M.; van Dongen, J.J.; Orlowska-Volk, M.; Knoth, R.; Durandy, A.; et al. Human ICOS deficiency abrogates the germinal center reaction and provides a monogenic model for common variable immunodeficiency. Blood 2006, 107, 3045-3052.

81. Briere, F.; Bridon, J.M.; Chevet, D.; Souillet, G.; Bienvenu, F.; Guret, C.; Martinez-Valdez, H.; Banchereau, J. Interleukin 10 induces B lymphocytes from IgA-deficient patients to secrete IgA. J. Clin. Invest. 1994, 94, 97-104.

82. Avery, D.T.; Bryant, V.L.; Ma, C.S.; de Waal Malefyt, R.; Tangye, S.G. IL-21-induced isotype switching to IgG and IgA by human naive B cells is differentially regulated by IL-4. J. Immunol. 2008, 181, 1767-1779.

83. Borte, S.; Pan-Hammarstrom, Q.; Liu, C.; Sack, U.; Borte, M.; Wagner, U.; Graf, D.; Hammarstrom, L. Interleukin-21 restores immunoglobulin production ex vivo in patients with common variable immunodeficiency and selective IgA deficiency. Blood 2009, 114, 4089-4098.

84. Cubas, R.A.; Mudd, J.C.; Savoye, A.L.; Perreau, M.; van Grevenynghe, J.; Metcalf, T.; Connick, E.; Meditz, A.; Freeman, G.J.; Abesada-Terk, G., Jr.; et al. Inadequate T follicular cell help impairs B cell immunity during HIV infection. Nat. Med. 2013, 19, 494-499.

85. Kitani, A.; Strober, W. Regulation of C gamma subclass germ-line transcripts in human peripheral blood B cells. J. Immunol. 1993, 151, 3478-3488.

86. Kawano, Y.; Noma, T.; Yata, J. Regulation of human IgG subclass production by cytokines. IFN- $\gamma$ and IL-6 act antagonistically in the induction of human IgG1 but additively in the induction of IgG2. J. Immunol. 1994, 153, 4948-4958.

87. Kawano, Y.; Noma, T.; Kou, K.; Yoshizawa, I.; Yata, J. Regulation of human IgG subclass production by cytokines: Human IgG subclass production enhanced differentially by interleukin-6. Immunology 1995, 84, 278-284.

88. Kawano, Y.; Noma, T. Role of interleukin-2 and interferon- $\gamma$ in inducing production of $\operatorname{IgG}$ subclasses in lymphocytes of human newborns. Immunology 1996, 88, 40-48. 
89. Kondo, N.; Inoue, R.; Kasahara, K.; Fukao, T.; Kaneko, H.; Tashita, H.; Teramoto, T. Reduced expression of the interferon $\gamma$ messenger RNA in IgG2 deficiency. Scand. J. Immunol. 1997, 45, 227-230.

90. Buckner, C.M.; Moir, S.; Ho, J.; Wang, W.; Posada, J.G.; Kardava, L.; Funk, E.K.; Nelson, A.K.; Li, Y.; Chun, T.W.; et al. Characterization of plasmablasts in the blood of HIV-infected viremic individuals: Evidence for nonspecific immune activation. J. Virol. 2013, 87, 5800-5811.

91. Crum-Cianflone, N.F.; Collins, G.; Defang, G.; Iverson, E.; Eberly, L.E.; Duplessis, C.; Maguire, J.; Ganesan, A.; Agan, B.K.; Lalani, T.; et al. Immunoglobulin G subclass levels and antibody responses to the 2009 influenza A (H1N1) monovalent vaccine among human immunodeficiency virus (HIV)-infected and HIV-uninfected adults. Clin. Exp. Immunol. 2012, 168, 135-141.

92. Xu, W.; Santini, P.A.; Sullivan, J.S.; He, B.; Shan, M.; Ball, S.C.; Dyer, W.B.; Ketas, T.J.; Chadburn, A.; Cohen-Gould, L.; et al. HIV-1 evades virus-specific IgG2 and IgA responses by targeting systemic and intestinal B cells via long-range intercellular conduits. Nat. Immunol. 2009, 10, 1008-1017.

93. Raux, M.; Finkielsztejn, L.; Salmon-Ceron, D.; Bouchez, H.; Excler, J.L.; Dulioust, E.; Grouin, J.M.; Sicard, D.; Blondeau, C. IgG subclass distribution in serum and various mucosal fluids of HIV type 1-infected subjects. AIDS Res. Hum. Retroviruses 2000, 16, 583-594.

94. French, M.A.; Denis, K.A.; Dawkins, R.; Peter, J.B. Severity of infections in IgA deficiency: Correlation with decreased serum antibodies to pneumococcal polysaccharides and decreased serum IgG2 and/or IgG4. Clin. Exp. Immunol. 1995, 100, 47-53.

95. Pallikkuth, S.; Parmigiani, A.; Silva, S.Y.; George, V.K.; Fischl, M.; Pahwa, R.; Pahwa, S. Impaired peripheral blood T-follicular helper cell function in HIV-infected nonresponders to the 2009 H1N1/09 vaccine. Blood 2012, 120, 985-993.

96. French, M.A.; Tanaskovic, S.; Law, M.G.; Lim, A.; Fernandez, S.; Ward, L.D.; Kelleher, A.D.; Emery, S. Vaccine-induced IgG2 anti-HIV p24 is associated with control of HIV in patients with a "high-affinity" Fc $\gamma$ RIIa genotype. AIDS 2010, 24, 1983-1990.

97. Perreau, M.; Savoye, A.L.; de Crignis, E.; Corpataux, J.M.; Cubas, R.; Haddad, E.K.; de Leval, L.; Graziosi, C.; Pantaleo, G. Follicular helper T-cells serve as the major CD4 T-cell compartment for HIV-1 infection, replication, and production. J. Exp. Med. 2012, 210, 143-156.

98. Oliveira, T.M.; Mineo, T.W.; Bason, M.; Day, M.J.; Machado, R.Z. IgG subclass profile of serum antibodies to Leishmania chagasi in naturally infected and vaccinated dogs. Vet. Parasitol. 2009, $162,16-22$.

99. Titanji, K.; Velu, V.; Chennareddi, L.; Vijay-Kumar, M.; Gewirtz, A.T.; Freeman, G.J.; Amara, R.R. Acute depletion of activated memory B cells involves the PD-1 pathway in rapidly progressing SIV-infected macaques. J. Clin. Invest. 2010, 120, 3878-3890.

(C) 2013 by the authors; licensee MDPI, Basel, Switzerland. This article is an open access article distributed under the terms and conditions of the Creative Commons Attribution license (http://creativecommons.org/licenses/by/3.0/). 